Article

\title{
Effect of methanol concentration on oxygen reduction reaction activity of Pt/C catalysts
}

\author{
TANG Shuihua a,b,c,*, LIN Wenfeng b, Paul A. CHRISTENSEN b, Geir Martin HAARBERG c \\ ${ }^{a}$ State Key Lab of Oil and Gas Reservoir Geology \& Exploitation, Southwest Petroleum University, Chengdu 610500, Sichuan, China \\ ${ }^{b}$ School of Chemical Engineering and Advanced Materials, Newcastle University, NE1 7RU Newcastle upon Tyne, United Kingdom \\ c Department of Materials Science and Engineering, Norwegian University of Science and Technology, Trondheim 7491, Norway
}

\section{A R T I C L E I N F O}

\section{Article history:}

Received 6 November 2012

Accepted 14 November 2012

Published 20 June 2013

\section{Keywords:}

Platinum

Carbon

Methanol crossover

Oxygen reduction

Fuel cell

\begin{abstract}
A B S T R A C T
The oxygen reduction reaction (ORR) activity of $\mathrm{Pt} / \mathrm{C}$ catalysts was investigated in electrolytes of 0.5 mol/ $\mathrm{L} \mathrm{H}_{2} \mathrm{SO}_{4}$ containing varying concentrations of methanol in a half-cell. It was found that the ORR activity was improved notably in an electrolyte of $0.5 \mathrm{~mol} / \mathrm{L} \mathrm{H}_{2} \mathrm{SO}_{4}$ containing $0.1 \mathrm{~mol} / \mathrm{L} \mathrm{CH}_{3} \mathrm{OH}$ as compared with that in $0.5 \mathrm{~mol} / \mathrm{L} \mathrm{H}_{2} \mathrm{SO}_{4}, 0.5 \mathrm{~mol} / \mathrm{L} \mathrm{H}_{2} \mathrm{SO}_{4}$ containing $0.5 \mathrm{~mol} / \mathrm{L} \mathrm{CH} 3 \mathrm{OH}$, or $0.5 \mathrm{~mol} / \mathrm{L}$ $\mathrm{H}_{2} \mathrm{SO}_{4}$ containing $1.0 \mathrm{~mol} / \mathrm{L} \mathrm{CH}_{3} \mathrm{OH}$ electrolytes. The same tendency for improved ORR activity was also apparent after commercial Nafion ${ }^{\circledR}$ NRE-212 membrane was hot-pressed onto the catalyst layers. The linear sweep voltammetry results indicate that the ORR activities of the $\mathrm{Pt} / \mathrm{C}$ catalyst were almost identical in the $0.5 \mathrm{~mol} / \mathrm{L} \mathrm{H}_{2} \mathrm{SO}_{4}+0.1 \mathrm{~mol} / \mathrm{L} \mathrm{CH}_{3} \mathrm{OH}$ solution before and after coated with the Nafion ${ }^{\circledR}$ membrane. Electrochemical impedance spectroscopy results demonstrated that the resistance of the Nafion ${ }^{\circledR}$ membrane is smaller in the electrolyte of $0.5 \mathrm{~mol} / \mathrm{L} \mathrm{H}_{2} \mathrm{SO}_{4}+0.1 \mathrm{~mol} / \mathrm{L}$ $\mathrm{CH}_{3} \mathrm{OH}$ than in other electrolytes with oxygen gas feed. This exceptional property of the Nafion ${ }^{\circledR}$ membrane is worth investigating and can be applied in fuel cell stacks to improve the system performance.
\end{abstract}

(C) 2013, Dalian Institute of Chemical Physics, Chinese Academy of Sciences. Published by Elsevier B.V. All rights reserved.

\section{Introduction}

The direct methanol fuel cell (DMFC) is one of the most promising candidates for portable power sources. One of the current challenges for this industry is methanol crossover that leads to the poisoning of cathode catalysts and environmental pollution [1-3]. Therefore, the development of a methanol resistant membrane and methanol-tolerant catalysts is of great importance in developing DMFCs.

Extensive studies have been carried out to improve the activities of catalysts [4,5], develop methanol resistant membranes [6-9], and methanol-tolerant catalysts [10-13]. Pd-Pt nanodendrites were synthesized by reducing $\mathrm{K}_{2} \mathrm{PtCl}_{4}$ with L-ascorbic acid in the presence of uniform Pd nanocrystal seeds. On the basis of equivalent Pt mass for the ORR, these were two and a half times more active in an aqueous solution than state-of-the-art Pt/C catalysts. They were also five times more active than first-generation Pt-black catalysts because of the controlled morphology of Pt nanostructures [4,5]. Ren et al. [6] prepared organic silica with thiol group/Nafion ${ }^{\circledR}$ composite membranes by using a casting method that used various additives including $\mathrm{HS}\left(\mathrm{CH}_{2}\right)_{3} \mathrm{CH}_{3} \mathrm{Si}\left(\mathrm{OCH}_{3}\right)_{2}(\mathrm{SH}-)$, tetraethyl orthosilicate (TEOS), and $\mathrm{HS}\left(\mathrm{CH}_{2}\right)_{3} \mathrm{CH}_{3} \mathrm{Si}\left(\mathrm{OCH}_{3}\right)_{2}$-TEOS (HS-TEOS) in Nafion ${ }^{\circledR}$ solutions. The $125 \mu \mathrm{m}$ SH-TEOS/ Nafion ${ }^{\circledR}$ composite membranes showed an approximately $50 \%$ decrease of methanol crossover compared with that of commercial Nafion ${ }^{\circledR} 117$ membrane. However, the proton conductivity of the membrane was slightly lowered. Core-shell PtM/C (M = Fe, Co, Ni, Pd, Cu, etc) catalysts are regarded as good methanol-tolerant catalysts because of their higher platinum surface area and unique alloy

*Corresponding author. Tel/Fax: +86-28-83032879; E-mail: shuihuatang@swpu.edu.cn

DOI: 10.1016/S1872-2067(11)60480-4 | http://www.sciencedirect.com/science/journal/18722067 | Chin. J. Catal., Vol. 34, No. 6, June 2013 
structure [10-13].

The influence of methanol on catalyst activity and catalyst layers have been investigated by AC impedance [14-18]. Du et al. [16] reported that the half-cell was ideal for the Electrochemical Impedance Spectroscopy studies of DMFC electrodes as the system not only facilitates an accurate potential control but also reflects the actual mass transport process that occurs in practical DMFCs. The steady-state results confirmed that the presence of methanol at the cathode could lead to a significant poisoning effect on the ORR, especially when the DMFC operates at higher methanol concentrations and discharges at lower potentials. Affoune et al. [17] measured the conductivity and surface morphology of Nafion ${ }^{\circledR} 117$ membranes in water and alcohol environments, where the conductivity was 0.1013 , $0.0206,0.0311,0.0667$, and $0.0912 \mathrm{~S} / \mathrm{cm}$ for water, pure methanol, and methanol- $\mathrm{H}_{2} \mathrm{O}$ solutions with $\mathrm{CH}_{3} \mathrm{OH} / \mathrm{H}_{2} \mathrm{O}$ volume ratios of $75 \%-25 \%, 50 \%-50 \%$, and $25 \%-75 \%$, respectively. The proton conductivity decreased with increasing methanol content [17]. Aricò et al. [18] used a gas diffusion electrode that mounted into a Teflon holder containing a platinum ring current collector and having an oxygen gas feed $(1 \times$ $10^{5} \mathrm{~Pa}, 200 \mathrm{~cm}^{3} / \mathrm{min}$ ) as the working electrode. The oxygen reduction behaviors of the electrodes coated and uncoated by $\mathrm{Nafion}^{\circledR}$ film were characterized in solutions of $2.5 \mathrm{~mol} / \mathrm{L}$ $\mathrm{H}_{2} \mathrm{SO}_{4}$ and $2.5 \mathrm{~mol} / \mathrm{L} \mathrm{H}_{2} \mathrm{SO}_{4}$ containing $0.5 \mathrm{~mol} / \mathrm{L} \mathrm{CH}_{3} \mathrm{OH}$ electrolyte. The oxygen reduction process was more favorable at low current densities with the $\mathrm{Nafion}^{\circledR}$ coated electrode. The open circuit voltage was approximately $200 \mathrm{mV}$ higher for this electrode than the analogous uncoated electrode. At current densities higher than $100 \mathrm{~mA} / \mathrm{cm}^{2}$, the activity of the prepared electrode surpasses that of the $\mathrm{Nafion}{ }^{\circledR}$ coated electrode. These phenomena have been interpreted on the basis of the large oxygen solubility of the $\mathrm{Nafion}{ }^{\circledR}$ electrolyte-electrode interface that causes a decrease of over-potential at low current density. Ohmic drop and mass transfer control significantly reduce the activity of Nafion ${ }^{\circledR}$-coated electrodes at high currents. At potentials lower than those corresponding to Pt-oxide reduction, methanol is oxidized even in the cathodic polarization [18].

In this paper, carbon diffusion layers were coated with Pt/C catalysts (Johnson Matthey Company) of different Pt loadings and investigated in a $0.5 \mathrm{~mol} / \mathrm{L} \mathrm{H}_{2} \mathrm{SO}_{4}$ solution containing varying concentrations of methanol. Commercial membrane Nafi${ }{ }^{\circledR}{ }^{\circledR}$ NRE-212 was then hot-pressed onto the surface of the catalyst layers and the half-membrane electrode assembly (half-MEA) was investigated under identical conditions. Several notable results were obtained when $\mathrm{Pt} / \mathrm{C}$ catalysts and the half-MEAs were tested in $0.5 \mathrm{~mol} / \mathrm{L} \mathrm{H}_{2} \mathrm{SO}_{4}$ solutions containing different concentrations of methanol.

\section{Experimental}

\subsection{Preparation of gas diffusion layer}

Toray carbon paper (TGP-H-030, Toray, Japan) was treated by a $6 \mathrm{wt} \%$ PTFE emulsion until the dry PTFE loading reached ca. $0.8 \mathrm{mg} / \mathrm{cm}^{2}$. The slurry of carbon black Vulcan XC72R and PTFE $(\mathrm{w} / \mathrm{o}=1: 1)$ was then brushed onto both sides of the PTFE-treated carbon paper until the carbon loading was approximately $1.5 \mathrm{~g} / \mathrm{cm}^{2}$. The gas diffusion layer was prepared after being treated at $340{ }^{\circ} \mathrm{C}$ for half an hour under nitrogen flow.

\subsection{Fabrication of working electrodes}

Pt/C (20 wt\% HiSPECTM 3000, Johnson Matthey) and Pt/C (50 wt\% HiSPECTM 8000, Johnson Matthey) catalyst inks were prepared with a mass ratio of 10:90 or 15:85 for dry Nafion ${ }^{\circledR} /$ catalyst, respectively. Cutting the gas diffusion layer into discs of $\emptyset=13\left(s=1.3273 \mathrm{~cm}^{2}\right)$, the catalyst ink was then dropped onto one side of the disc repeatedly. After the catalyst

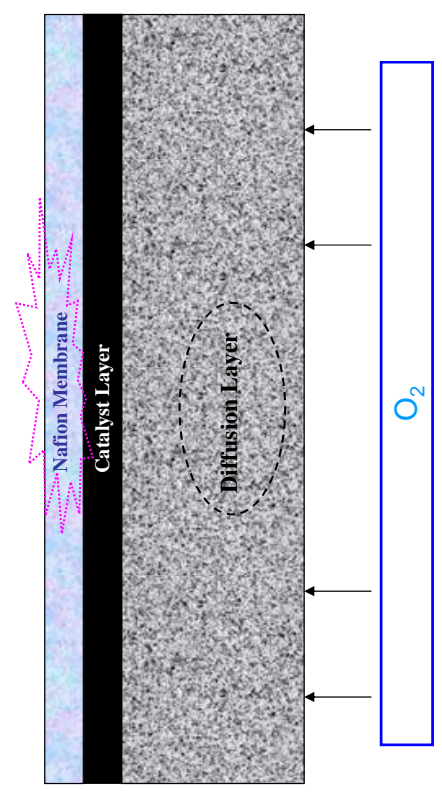

(a)

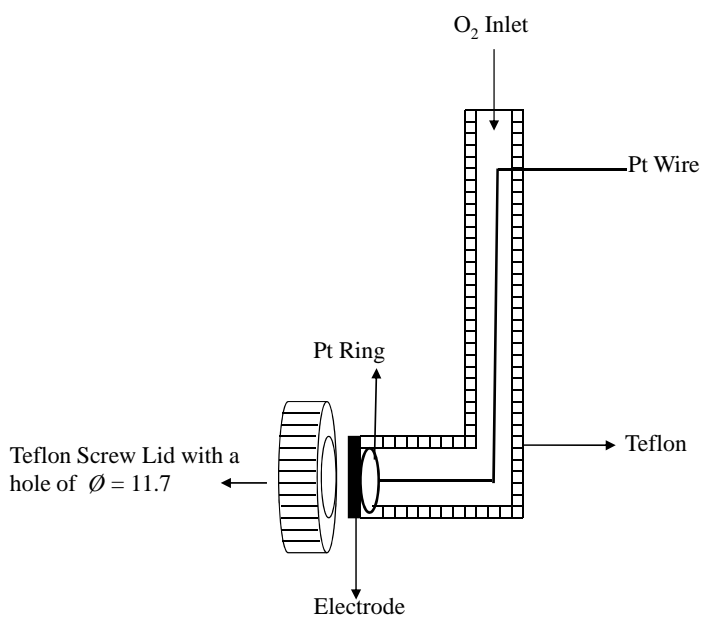

(b)

Fig. 1. Schematic structure of electrode (a) and configuration of working electrode (b). 
ink dried, the electrodes were treated in an oven at $80{ }^{\circ} \mathrm{C}$ for half an hour. Two parallel catalyst electrodes were fabricated and tested for each catalyst.

\subsection{Electrochemical measurements}

The ORR activity of $20 \mathrm{wt} \% \mathrm{Pt} / \mathrm{C}$ catalysts was tested in the electrolytes of $0.5 \mathrm{~mol} / \mathrm{L} \mathrm{H}_{2} \mathrm{SO}_{4}$ containing different concentrations of methanol. After that, the electrode was taken out of the electrolyte and rinsed with high purity of water, then dried in an $80^{\circ} \mathrm{C}$ oven. Subsequently Nafion ${ }^{\circledR}$ perfluorinated resin solution ( $5 \mathrm{wt} \%$ ) was dropped onto the top of the catalyst layer to form a thin film, then two layers of pre-treated commercial Nafion ${ }^{\circledR}$ membrane NRE-212 (Aldrich, Item\# 676470) were hot-pressed onto the catalyst layer one by one at $130{ }^{\circ} \mathrm{C}$, which is denoted as half-MEA. The above mentioned tests were performed again. At the same time, a new untested electrode was hot-pressed with Nafion ${ }^{\circledR}$ NRE-212 membrane and subsequently investigated. For $50 \mathrm{wt} \% \mathrm{Pt} / \mathrm{C}$ (HiSPECTM 8000, Johnson Matthey) catalysts, both electrodes were hot-pressed with two layers of Nafion ${ }^{\circledR}$ NRE-212 membrane before testing.

The configuration of the half-MEA is shown in Fig. 1 (a). The electrode or half-MEA was mounted onto a Teflon skeleton with the catalyst layer or Nafion ${ }^{\circledR}$ membrane exposed to the electrolyte. Oxygen was introduced from the back of the catalyst layer as shown in Fig. 1 (b), which is similar to that described in reference [18]. All measurements were carried out in a three-electrode cell. A Pt slice was used as the counter electrode, and $\mathrm{Ag} / \mathrm{AgCl}(\mathrm{s})$ electrode was used as the reference electrode. The potentials mentioned below were recorded against $\mathrm{Ag} / \mathrm{AgCl}(\mathrm{s})$ unless noted. Oxygen was introduced for more than 10 min before linear sweep voltammetry (LSV) tests or electrochemical impedance spectroscopy (EIS) measurements. After changing the electrolyte, oxygen was stopped for half an hour to ensure the replaced electrolyte efficiently gets access to the catalyst layer. The electrodes were not rinsed if they were placed in more concentrated electrolyte; however, they were rinsed with high purity de-ionized water when placed in a diluted electrolyte.

\section{Results and discussion}

The compositions of the electrodes or half-MEAs of $20 \mathrm{wt} \%$ $\mathrm{Pt} / \mathrm{C}$ and $50 \mathrm{wt} \% \mathrm{Pt} / \mathrm{C}$ catalysts are listed in Table 1.

\subsection{Influence of methanol concentration on ORR activity}

The ORR activities of $20 \mathrm{wt} \% \mathrm{Pt} / \mathrm{C}$ catalysts in different

Table 1

The parameters of electrodes or half-MEAs.

\begin{tabular}{lcccc}
\hline Item & $\begin{array}{c}\text { Catalyst } \\
\text { mass } \\
(\mathrm{mg})\end{array}$ & $\begin{array}{c}5 \mathrm{wt} \% \\
\text { Nafion } \\
\text { solution }\end{array}$ & $\begin{array}{c}\text { Pt loading } \\
\left(\mathrm{mg}_{\mathrm{Pt}} / \mathrm{cm}^{2}\right)\end{array}$ & $\begin{array}{c}\text { Nafion } \\
{ }^{\circledR} \\
\text { loading } \\
\left(\mathrm{mg} / \mathrm{cm}^{2}\right)\end{array}$ \\
\hline 20 wt\% Pt/C & $10.4 \mathrm{wt} \%$ & dry Nafion $^{\circledR}$ & 0.47 & 24.5 \\
(Johnson Matthey) & & & 0.62 & $\mathrm{~N} / \mathrm{A}$ \\
50 wt\% Pt/C & $15.0 \mathrm{wt} \%$ & dry Nafion $^{\circledR}$ & 4.13 & 25.5 \\
(Johnson Matthey) & & & 4.74 & 26.8 \\
\hline
\end{tabular}

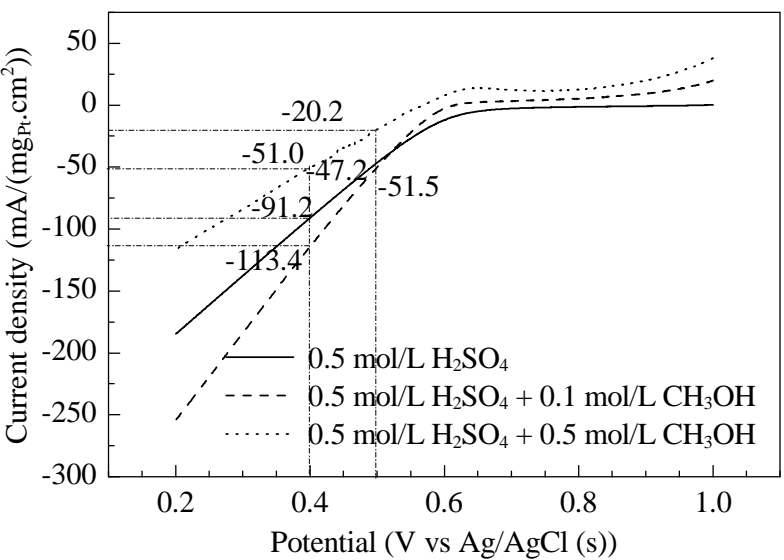

Fig. 2. LSV curves of $20 \mathrm{wt} \% \mathrm{Pt} / \mathrm{C}$ (Johnson Matthey) in different electrolyte at room temperature. Potential scan range of $1.1-0.2 \mathrm{~V}$ vs $\mathrm{Ag} / \mathrm{AgCl}(\mathrm{s}$ ), scan rate of $5 \mathrm{mV} / \mathrm{s}$, and oxygen flow rate of $50 \mathrm{ml} / \mathrm{min}$.

electrolytes are shown in Fig. 2. In the potential range from 1.1-0.7 V, the current density is noted to be influenced by methanol concentration. The curve at $\sim 0.64 \mathrm{~V}$ can be assigned as the combination of methanol and oxygen, where the methanol creates an oxidation current and the oxygen causes a reduction current. In the $0.5 \mathrm{~mol} / \mathrm{L} \mathrm{H}_{2} \mathrm{SO}_{4}$ electrolyte, there is no oxidation current of methanol, and the onset potential of oxygen reduction is approximately $0.62 \mathrm{~V}$. In $0.5 \mathrm{~mol} / \mathrm{L} \mathrm{H}_{2} \mathrm{SO}_{4}+0.1$ mol/ $/ \mathrm{CH}_{3} \mathrm{OH}$ electrolyte, the oxidation current of methanol is almost offset by the reduction current of the oxygen. However, if the electrolyte contains more concentrated methanol, the oxidation current of methanol is higher than the reduction current of oxygen.

At a potential of $0.5 \mathrm{~V}$, the ORR activity is -47.2 $\mathrm{mA} /\left(\mathrm{mg}_{\mathrm{Pt} . \mathrm{cm}^{2}}\right)$ in $0.5 \mathrm{~mol} / \mathrm{L} \mathrm{H}_{2} \mathrm{SO}_{4}$. It is $-51.5 \mathrm{~mA} /\left(\mathrm{mgPt}_{\mathrm{Pt}} \mathrm{cm}^{2}\right)$ in $0.5 \mathrm{H}_{2} \mathrm{SO}_{4}+0.1 \mathrm{~mol} / \mathrm{L} \mathrm{CH} 3 \mathrm{OH}$ and $-20.2 \mathrm{~mA} /\left(\mathrm{mg}_{\left.\mathrm{Pt} . \mathrm{cm}^{2}\right)}\right)$ in $0.5 \mathrm{H}_{2} \mathrm{SO}_{4}+0.5 \mathrm{~mol} / \mathrm{L} \mathrm{CH}_{3} \mathrm{OH}$. At a potential of $0.4 \mathrm{~V}$, the ORR activity was enhanced from $-91.2 \mathrm{~mA} /\left(\mathrm{mgPt}_{\mathrm{Pt}} \mathrm{cm}^{2}\right)$ to -113.4 $\mathrm{mA} /\left(\mathrm{mg}_{\mathrm{Pt} . \mathrm{cm}^{2}}\right)$ when replacing the $0.5 \mathrm{~mol} / \mathrm{L} \mathrm{H}_{2} \mathrm{SO}_{4}$ solution by $0.5 \mathrm{~mol} / \mathrm{L} \mathrm{H}_{2} \mathrm{SO}_{4}+0.1 \mathrm{~mol} / \mathrm{L} \mathrm{CH}_{3} \mathrm{OH}$. However, the activity decreased to $-51.0 \mathrm{~mA} /\left(\mathrm{mgPt}_{\mathrm{Pt}} \mathrm{cm}^{2}\right)$ when replaced by $0.5 \mathrm{~mol} / \mathrm{L}$ $\mathrm{H}_{2} \mathrm{SO}_{4}+0.5 \mathrm{~mol} / \mathrm{L} \mathrm{CH}_{3} \mathrm{OH}$. The effect of methanol concentration on the ORR activity is highly noticeable. Previously, it had only been considered that methanol causes poisoning of the cathode $\mathrm{Pt} / \mathrm{C}$ catalyst, so the study of methanol-tolerant catalysts was determined as one of the most important aspects in the development of DMFCs [10-13]. However, from the results above, the ORR activity of $\mathrm{Pt} / \mathrm{C}$ catalysts has been shown to improve significantly in a $0.5 \mathrm{~mol} / \mathrm{L} \mathrm{H}_{2} \mathrm{SO}_{4}+0.1 \mathrm{~mol} / \mathrm{L} \mathrm{CH}_{3} \mathrm{OH}$ electrolyte. If the ORR activity of Pt/C catalysts in a $0.5 \mathrm{~mol} / \mathrm{L} \mathrm{H}_{2} \mathrm{SO}_{4}+$ $0.1 \mathrm{~mol} / \mathrm{L} \mathrm{CH}_{3} \mathrm{OH}$ solution can be used in DMFC stacks by specialized design, system performance can be improved.

To gain more practical data, the half-MEA with two layers of pre-treated Nafion ${ }^{\circledR}$ NRE-212 membrane hot-pressed on the catalyst layer were investigated. The LSV curves of the half-MEA of $20 \mathrm{wt} \% \mathrm{Pt} / \mathrm{C}$ catalyst in $0.5 \mathrm{~mol} / \mathrm{L} \mathrm{H}_{2} \mathrm{SO}_{4}, 0.5 \mathrm{~mol} / \mathrm{L}$ $\mathrm{H}_{2} \mathrm{SO}_{4}+0.1 \mathrm{CH}_{3} \mathrm{OH}$, and $0.5 \mathrm{~mol} / \mathrm{L} \mathrm{H}_{2} \mathrm{SO}_{4}+0.5 \mathrm{CH}_{3} \mathrm{OH}$ solutions are shown in Fig. 3. As the Nafion ${ }^{\circledR}$ membrane may have covered some active sites of the catalyst, the ORR activity of the 


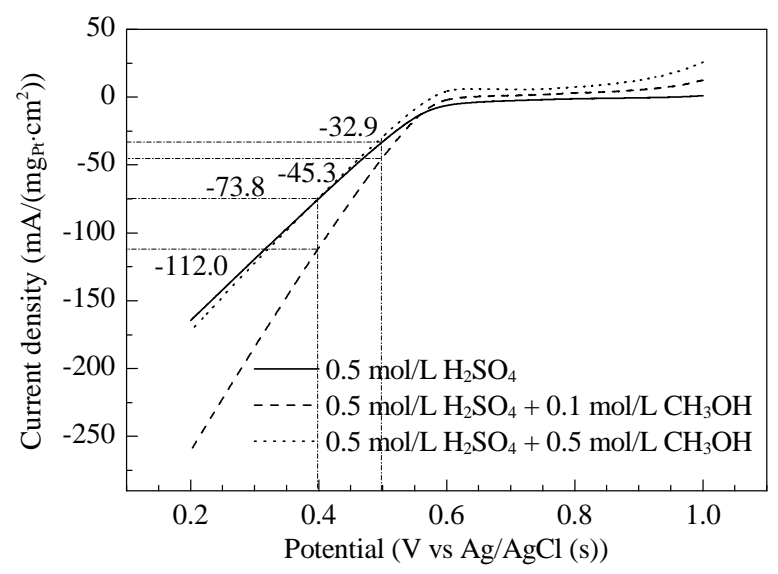

Fig. 3. LSV curves of $20 \mathrm{wt} \% \mathrm{Pt} / \mathrm{C}$ (Johnson Matthey) after coated with two layers of commercial Nafion ${ }^{\circledR}$ membrane NRE-212. Potential scan range of $1.1-0.2 \mathrm{~V}$ vs $\mathrm{Ag} / \mathrm{AgCl}(\mathrm{s})$, scan rate of $5 \mathrm{mV} / \mathrm{s}$ and oxygen flow rate of $25 \mathrm{ml} / \mathrm{min}$ at room temperature.

catalyst in $0.5 \mathrm{~mol} / \mathrm{L} \mathrm{H}_{2} \mathrm{SO}_{4}$ solution decreased from -91.2 to $-75.8 \mathrm{~mA} /\left(\mathrm{mg}_{\mathrm{Pt} . \mathrm{cm}^{2}}\right)$. In the $0.5 \mathrm{~mol} / \mathrm{L} \mathrm{H}_{2} \mathrm{SO}_{4}+0.5 \mathrm{CH}_{3} \mathrm{OH}$ solution, the Nafion ${ }^{\circledR}$ membrane can prevent the $\mathrm{Pt} / \mathrm{C}$ catalyst from being exposed to methanol directly, thus improving the ORR activity. The behavior is similar to that recorded in the absence of methanol at potentials lower than $0.5 \mathrm{~V}$. As in the $0.5 \mathrm{~mol} / \mathrm{L} \mathrm{H}_{2} \mathrm{SO}_{4}+0.1 \mathrm{~mol} / \mathrm{L} \mathrm{CH}_{3} \mathrm{OH}$ solution, the catalyst activity was barely affected by the Nafion ${ }^{\circledR}$ membrane, because it was almost identical to that of the uncoated electrode, as shown in Fig. 4. It appears that the Nafion ${ }^{\circledR}$ membrane did not cover the active sites and the methanol did not lead to poisoning of the catalyst in the $0.5 \mathrm{~mol} / \mathrm{L} \mathrm{H}_{2} \mathrm{SO}_{4}+0.1 \mathrm{~mol} / \mathrm{L} \mathrm{CH}_{3} \mathrm{OH}$ electrolyte. The ORR activity was significantly enhanced compared with that in the $0.5 \mathrm{~mol} / \mathrm{L} \mathrm{H}_{2} \mathrm{SO}_{4}$ solution. This could be due to more open micro-channels for proton transfer in the Nafion ${ }^{\circledR}$ membrane other than the swelling in the $0.5 \mathrm{~mol} / \mathrm{L}$ $\mathrm{H}_{2} \mathrm{SO}_{4}+0.1 \mathrm{~mol} / \mathrm{L} \mathrm{CH}_{3} \mathrm{OH}$ electrolyte, which could subsequently lead to smaller resistance of the Nafion ${ }^{\circledR}$ membrane. This tendency may also be because of the promotion effect of methanol in the oxygen reduction reaction in the $0.5 \mathrm{~mol} / \mathrm{L} \mathrm{H}_{2} \mathrm{SO}_{4}+$ $0.1 \mathrm{~mol} / \mathrm{L} \mathrm{CH}_{3} \mathrm{OH}$ electrolyte, which could lead to reduced charge transfer resistance.

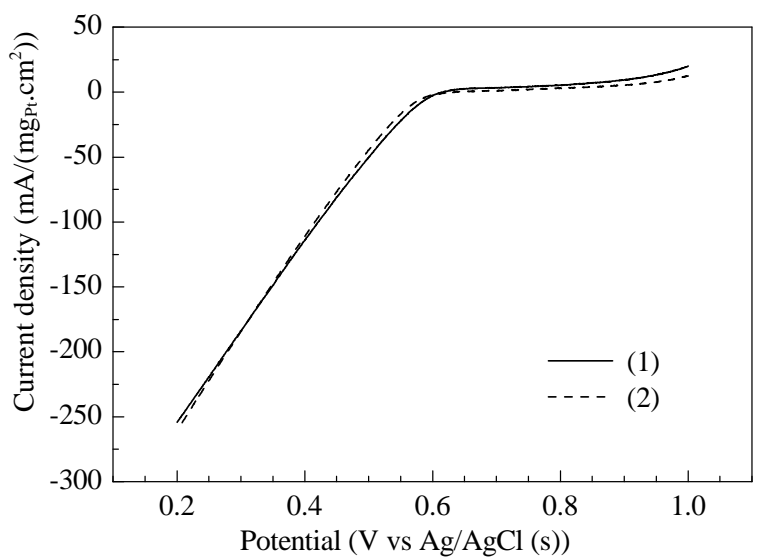

Fig. 4. Comparison of LSV curves of 20 wt $\%$ Pt/C (Johnson Matthey) before (1) and after coated with Nafion ${ }^{\circledR}$ membrane NRE-212 (2).
Usually in a single cell or stack, $1.0 \mathrm{~mol} / \mathrm{L}$ or higher concentrations of $\mathrm{CH}_{3} \mathrm{OH}$ solution are introduced as fuel. At the potential of $0.5 \mathrm{~V}$, the ORR activity of the half-MEA of $20 \mathrm{wt} \% \mathrm{Pt} / \mathrm{C}$ catalyst can increase from -22.5 to $-54.0 \mathrm{~mA} /\left(\mathrm{mg}_{\mathrm{Pt} . \mathrm{cm}^{2}}\right)$ after the electrode is transferred from the $0.5 \mathrm{~mol} / \mathrm{L} \mathrm{H}_{2} \mathrm{SO}_{4}+1.0$ $\mathrm{mol} / \mathrm{L} \mathrm{CH}_{3} \mathrm{OH}$ to the $0.5 \mathrm{~mol} / \mathrm{L} \mathrm{H}_{2} \mathrm{SO}_{4}+0.1 \mathrm{~mol} / \mathrm{L} \mathrm{CH}_{3} \mathrm{OH}$ electrolyte. At the potential of $0.4 \mathrm{~V}$, the ORR activity can increase from -71.5 to $-126.4 \mathrm{~mA} /\left(\mathrm{mg}_{\mathrm{Pt} . \mathrm{cm}^{2}}\right)$. Furthermore, the ORR activity of the $\mathrm{Pt} / \mathrm{C}$ catalyst in the $0.5 \mathrm{~mol} / \mathrm{L} \mathrm{H}_{2} \mathrm{SO}_{4}+0.1 \mathrm{~mol} / \mathrm{L}$ $\mathrm{CH}_{3} \mathrm{OH}$ solution can be recovered after being tested in the 0.5 mol/ $/ \mathrm{L}_{2} \mathrm{SO}_{4}+1.0 \mathrm{~mol} / \mathrm{L} \mathrm{CH}_{3} \mathrm{OH}$ solution, and even enhanced slightly after several cycles. The LSV curves are shown in Fig. 5.

To further support practical stack application, $50 \mathrm{wt} \% \mathrm{Pt} / \mathrm{C}$ catalysts with a catalyst loading of ca. $4.0 \mathrm{mg} \mathrm{gt}_{\mathrm{Pt}} / \mathrm{cm}^{2}$ were investigated. The ORR activities of half-MEA of $50 \mathrm{wt} \% \mathrm{Pt} / \mathrm{C}$ catalysts in a $0.5 \mathrm{~mol} / \mathrm{L} \mathrm{H}_{2} \mathrm{SO}_{4}$ solution containing different methanol concentrations are shown in Fig. 6. A similar trend was obtained for $50 \mathrm{wt} \% \mathrm{Pt} / \mathrm{C}$ catalysts. The ORR activities of the catalysts were almost identical in $0.5 \mathrm{~mol} / \mathrm{L} \mathrm{H}_{2} \mathrm{SO}_{4}, 0.5 \mathrm{~mol} / \mathrm{L}$ $\mathrm{H}_{2} \mathrm{SO}_{4}+0.5 \mathrm{~mol} / \mathrm{L} \mathrm{CH}_{3} \mathrm{OH}$, and $0.5 \mathrm{~mol} / \mathrm{L} \mathrm{H}_{2} \mathrm{SO}_{4}+1.0 \mathrm{~mol} / \mathrm{L}$ $\mathrm{CH}_{3} \mathrm{OH}$ solutions at potentials of lower than $0.5 \mathrm{~V}$, but was enhanced in $0.5 \mathrm{~mol} / \mathrm{L} \mathrm{H}_{2} \mathrm{SO}_{4}+0.1 \mathrm{~mol} / \mathrm{L} \mathrm{CH}_{3} \mathrm{OH}$. The most noticeable differences in electrolytes containing varying concentrations of methanol were observed at potentials higher than $0.6 \mathrm{~V}$. More serious methanol crossover was observed in higher concentrations of methanol solutions that produced a larger methanol oxidization current. However, at potentials lower than $0.5 \mathrm{~V}$, they demonstrated similar activities, except for that in the $0.5 \mathrm{~mol} / \mathrm{L} \mathrm{H}_{2} \mathrm{SO}_{4}+0.1 \mathrm{~mol} / \mathrm{L} \mathrm{CH}_{3} \mathrm{OH}$ solution.

From Figs. 3 and 5, the methanol crossover affects the LSV curves at potentials higher than ca. $0.5 \mathrm{~V}$, but has little influence at lower potentials. This implies that the oxygen reduction reaction is dominant at lower potentials, with methanol only contributing a very slight oxidation current or none at all. The onset potentials shifted cathodically in $0.5 \mathrm{~mol} / \mathrm{L} \mathrm{H}_{2} \mathrm{SO}_{4}+0.5$ $\mathrm{mol} / \mathrm{L} \mathrm{CH}_{3} \mathrm{OH}$ or $0.5 \mathrm{~mol} / \mathrm{L} \mathrm{H}_{2} \mathrm{SO}_{4}+1.0 \mathrm{~mol} / \mathrm{L} \mathrm{CH} 3 \mathrm{OH}$ solutions as the active sites of the $\mathrm{Pt} / \mathrm{C}$ catalysts were occupied by CO-like intermediates from the methanol oxidation reaction at

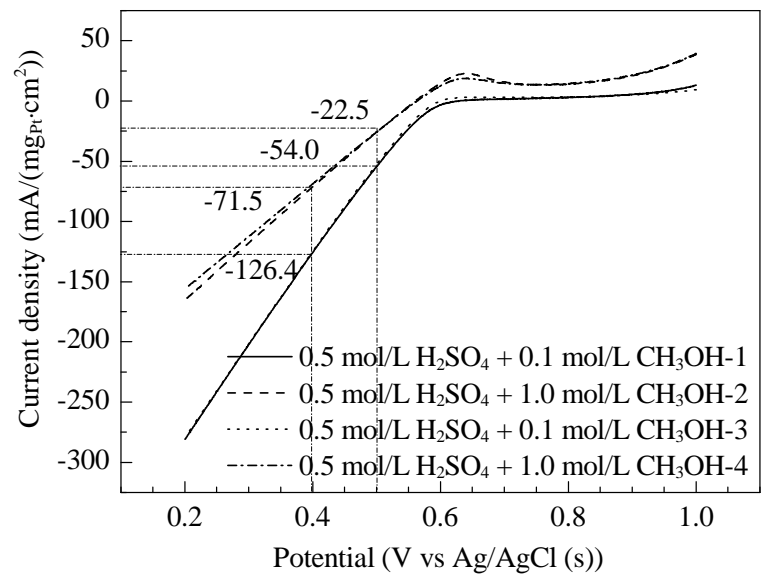

Fig. 5. LSV curves of $20 \mathrm{wt} \% \mathrm{Pt} / \mathrm{C}$ (Johnson Matthey) coated with Nafion ${ }^{\circledR}$ membrane NRE-212 were tested in different electrolytes at room temperature. Numbers $1,2,3$, and 4 were used to denote the testing sample sequence. 


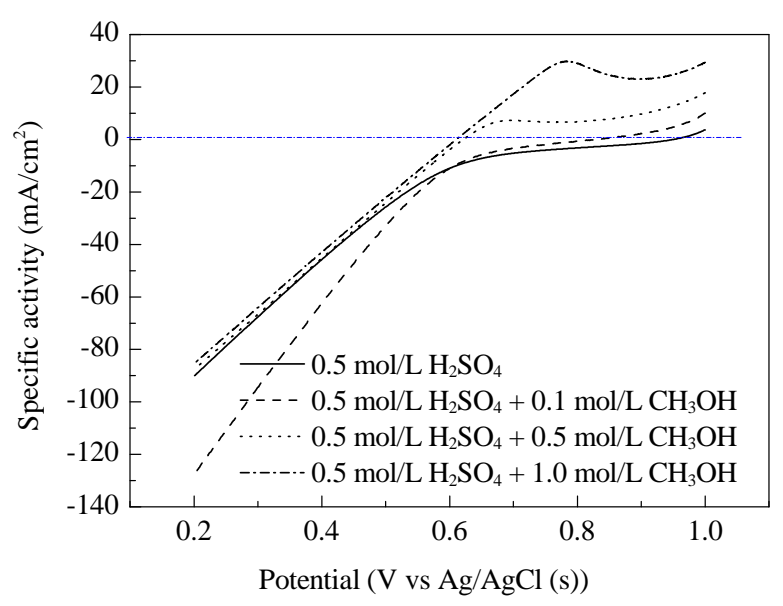

Fig. 6. Comparison of linear sweep voltammetry of $50 \mathrm{wt} \% \mathrm{Pt} / \mathrm{C}$ (Johnson Matthey) coated with Nafion ${ }^{\circledR}$ membrane NRE-212 in different electrolytes at room temperature.

higher potentials, leading to the poisoning of $\mathrm{Pt} / \mathrm{C}$ catalysts. However, it is not clear why small amounts of methanol in the electrolyte do not lead to poisoning of $\mathrm{Pt} / \mathrm{C}$ catalysts, rather than improving the ORR activity.

During preparation of the catalyst ink, the catalyst particles were partly covered by a Nafion ${ }^{\circledR}$ thin film, so the catalysts utilization is usually less than $20 \%$. The methanol solution can open or enlarge the proton transfer micro-channels of the Nafion ${ }^{\circledR}$ membrane, which would lead to methanol crossover and membrane swelling. However, more open micro-channels can lead to higher proton transfer capacity, and more oxygen can get access to active sites of $\mathrm{Pt} / \mathrm{C}$ catalysts. More active sites of the Pt/C catalyst can be exposed to oxygen and/or proton thus the three-phase interfaces can be more easily maintained, which is defined as a promotional effect of methanol. If the methanol concentration is too high, the methanol crossover and membrane swelling will be more serious, thus the negative effects of methanol will dominate. However, if the methanol concentration is within acceptable limits, methanol can maximize the capacity of proton transfer, and more oxygen can access more active sites, thus promoting the positive effects of

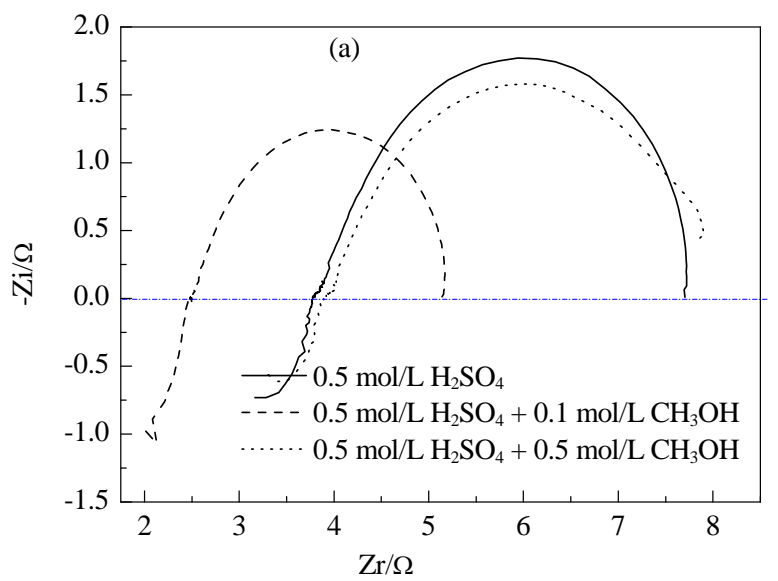

methanol, such as in the $0.5 \mathrm{~mol} / \mathrm{L} \mathrm{H}_{2} \mathrm{SO}_{4}+0.1 \mathrm{~mol} / \mathrm{L} \mathrm{CH}_{3} \mathrm{OH}$ solution. Affoune et al. [17] measured the proton conductivity of Nafion ${ }^{\circledR} 117$ membrane in a $\mathrm{CH}_{3} \mathrm{OH} / \mathrm{H}_{2} \mathrm{O}$ electrolyte with volume ratios of $75 \%-25 \%, 50 \%-50 \%$, and $25 \%-75 \%$. They drew the conclusion that proton conductivity decreased with increased methanol content. However, the most dilute electrolyte used in their paper was of $25 \%$ methanol- $75 \% \mathrm{H}_{2} \mathrm{O}$, with a molar concentration of ca. $6.0 \mathrm{~mol} / \mathrm{L}$, which is too concentrated as a direct feed fuel for DMFCs. Thus their conclusion is not applicable in this study.

\subsection{Influence of methanol concentration on AC impedance}

Electrochemical impedance spectroscopy can be a helpful technique to probe reaction processes [14-18]. For identical system configurations, the difference in impedance spectroscopes can reflect the differences in the EC or half-MEA. Half-MEAs of $20 \mathrm{wt} \% \mathrm{Pt} / \mathrm{C}$ and $50 \mathrm{wt} \% \mathrm{Pt} / \mathrm{C}$ catalysts in a 0.5 mol/L $\mathrm{H}_{2} \mathrm{SO}_{4}$ solution containing different concentrations of methanol were measured at different potentials in a frequency range from $100 \mathrm{kHz}-10 \mathrm{mHz}$.

Nyquist plots are demonstrated in Fig. 7 for half-MEAs of 20 wt $\% \mathrm{Pt} / \mathrm{C}$ and $50 \mathrm{wt} \% \mathrm{Pt} / \mathrm{C}$ catalysts in $0.5 \mathrm{~mol} / \mathrm{L} \mathrm{H}_{2} \mathrm{SO}_{4}$ electrolytes containing different contents of methanol. Electrolyte resistance was $3.81 \Omega$ for the half-MEA of $20 \mathrm{wt} \% \mathrm{Pt} / \mathrm{C}$ catalyst in $0.5 \mathrm{~mol} / \mathrm{L} \mathrm{H}_{2} \mathrm{SO}_{4}, 2.49 \Omega$ for the solution of $0.5 \mathrm{~mol} / \mathrm{L} \mathrm{H}_{2} \mathrm{SO}_{4}+$ $0.1 \mathrm{~mol} / \mathrm{L} \mathrm{CH} \mathrm{CH}_{3} \mathrm{OH}$, and $3.88 \Omega$ for the $0.5 \mathrm{~mol} / \mathrm{L} \mathrm{H}_{2} \mathrm{SO}_{4}+0.5$ mol/L $\mathrm{CH}_{3} \mathrm{OH}$ electrolyte. The resistances were slightly larger in $0.5 \mathrm{~mol} / \mathrm{L} \mathrm{H}_{2} \mathrm{SO}_{4}+0.5 \mathrm{~mol} / \mathrm{L} \mathrm{CH}_{3} \mathrm{OH}$ than in $0.5 \mathrm{~mol} / \mathrm{L} \mathrm{H}_{2} \mathrm{SO}_{4}$, but were much smaller in $0.5 \mathrm{~mol} / \mathrm{L} \mathrm{H}_{2} \mathrm{SO}_{4}+0.1 \mathrm{~mol} / \mathrm{L} \mathrm{CH}_{3} \mathrm{OH}$. The same tendency was observed for the half-MEA of $50 \mathrm{wt} \%$ $\mathrm{Pt} / \mathrm{C}$ catalysts. The resistances were $3.80 \Omega$ for the half-MEA of $50 \mathrm{wt} \% \mathrm{Pt} / \mathrm{C}$ catalyst in $0.5 \mathrm{~mol} / \mathrm{L} \mathrm{H}_{2} \mathrm{SO}_{4}, 2.63 \Omega$ for the 0.5 $\mathrm{mol} / \mathrm{L} \mathrm{H}_{2} \mathrm{SO}_{4}+0.1 \mathrm{~mol} / \mathrm{L} \mathrm{CH}_{3} \mathrm{OH}$ solution, $3.96 \Omega$ for $0.5 \mathrm{~mol} / \mathrm{L}$ $\mathrm{H}_{2} \mathrm{SO}_{4}+0.5 \mathrm{~mol} / \mathrm{L} \mathrm{CH}_{3} \mathrm{OH}$, and $4.12 \Omega$ in $0.5 \mathrm{~mol} / \mathrm{L} \mathrm{H}_{2} \mathrm{SO}_{4}+1.0$ mol/L $\mathrm{CH}_{3} \mathrm{OH}$. The major difference between the two half-MEAs lies in the charge transfer resistance. The half-MEA of $50 \mathrm{wt} \% \mathrm{Pt} / \mathrm{C}$ catalyst with high platinum loading (more than $4 \mathrm{mgPt} / \mathrm{cm}^{2}$ ) demonstrated a smaller charge transfer resistance,

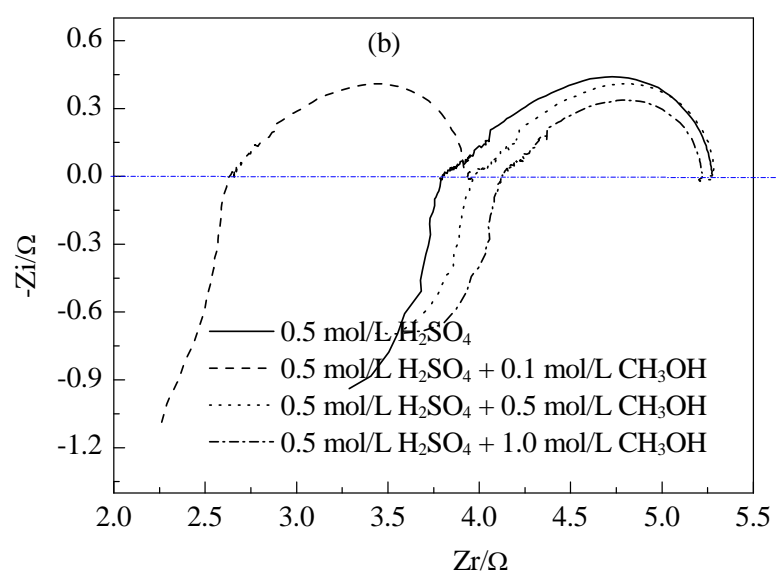

Fig. 7. Nyquist plots of 20 wt $\%$ Pt/C (a) and 50 wt\% Pt/C (b) coated with Nafion ${ }^{\circledR}$ membrane NRE-212 at potential of $500 \mathrm{mV}$ with potential step of $10 \mathrm{mV}$ and $\mathrm{AC}$ sine wave amplitude of $10 \mathrm{mV}$ between $100 \mathrm{kHz}$ and $10 \mathrm{mHz}$, in $0.5 \mathrm{~mol} / \mathrm{L} \mathrm{H}_{2} \mathrm{SO}_{4}$ containing varying concentrations of $\mathrm{CH}_{3} \mathrm{OH}$ at room temperature. 
that is why high Pt loading is needed for DMFCs. As more concentrated methanol in the electrolyte was applied, smaller charge transfer resistances were observed. This indicates that in some cases, methanol can facilitate the charge transfer process in the oxygen reduction reaction. This is consistent with the reports by Aricò et al. [18].

The EIS results were found to correlate with the ORR activity results. As mentioned previously, more micro-channels of the Nafion ${ }^{\circledR}$ membrane were enlarged because of the oxygen gas present in the $0.5 \mathrm{~mol} / \mathrm{L} \mathrm{H}_{2} \mathrm{SO}_{4}+0.1 \mathrm{~mol} / \mathrm{L} \mathrm{CH}_{3} \mathrm{OH}$ solution, thus leading to the smaller resistances and improved ORR activity. This special property of Nafion ${ }^{\circledR}$ membranes can be used in designing a stack that will improve the performance of fuel cells. Pt/C catalysts (20 wt\%) from E-TEK company, in-house $\mathrm{Pt} / \mathrm{C}$ and PtCo/C catalysts were also measured and the same trends were obtained. The improved ORR activity of the $\mathrm{Pt} / \mathrm{C}$ catalysts in $0.5 \mathrm{~mol} / \mathrm{L} \mathrm{H}_{2} \mathrm{SO}_{4}+0.1 \mathrm{~mol} / \mathrm{L} \mathrm{CH}_{3} \mathrm{OH}$ solution has been noted in all the testing data. Further research will be carried out to investigate the theory behind these results.

\section{Conclusions}

Both catalysts of $20 \mathrm{wt} \% \mathrm{Pt} / \mathrm{C}$ and $50 \mathrm{wt} \% \mathrm{Pt} / \mathrm{C}$ (Johnson Matthey) showed much better oxygen reduction reaction activities in electrolytes in $0.5 \mathrm{~mol} / \mathrm{L} \mathrm{H}_{2} \mathrm{SO}_{4}$ solutions containing 0.1 mol/ $\mathrm{L} \mathrm{CH}_{3} \mathrm{OH}$. This was due to reduced electrolyte resistances. The charge transfer resistances can also be reduced in more concentrated methanol solutions by increasing the Pt loading of the electrode. High Pt loading at the electrode can be adopted for practical use and $0.1 \mathrm{~mol} / \mathrm{L} \mathrm{CH}_{3} \mathrm{OH}$ can be fed to a direct methanol fuel cell. This can increase the efficiency of the overall system and reduce environmental pollution for portable power devices.

\section{Acknowledgments}

I will be grateful to Prof. Reidar Tunold, Prof. Svein Sunde, Prof. Frøde Saland for their helpful discussions and suggestions.

\section{References}

[1] Tang S H, Sun G Q, Qi J, Sun S G, Guo J S, Xin Q, Haarberg G M. Chin J Catal (唐水花, 孙公权, 齐静, 孙世国, 郭军松, 辛勤, Haarberg G M. 催化学报), 2010, 31: 12

[2] Arico A S, Srinivasan S, Antonucci V. Fuel Cells, 2001, 1: 133

[3] Mauritz K A, Moore R B. Chem Rev, 2004, 104: 4535

[4] Lim B, Jiang M, Camargo P H C, Cho E C, Tao J, Lu X, Zhu Y, Xia Y. Science, 2009, 324: 1302

[5] Zhang G, Shao Z G, Lu W T, Li G F, Liu F Q, Yi B L. Electrochem Commun, 2012, 22: 145

[6] Ren S Z, Sun G Q Li C N, Liang Z X, Wu Z M, Jin W, Xin Q, Yang X F. J Membrane Sci, 2006, 282: 450

[7] Sun L L, Wang S L, Jin W, Hou H Y, Jiang L H, Sun G Q. Int J Hydrogen Energy, 2010, 35: 12461

[8] Qu S G, Li X J, Ke C C, Shao Z G, Yi B L. Chin J Power Sources (屈树国, 李晓锦, 柯长春, 邵志刚, 衣宝廉. 电源技术), 2011, 35: 1231

[9] Li J, Li X J, Zhao Y, Lu W T, Shao Z G, Yi B L. ChemSusChem, 2012, 5: 896

[10] Mani P, Srivastava R, Strasser P.J Phys Chem C, 2008, 112: 2770

[11] Wang J X, Inada H, Wu L, Zhu Y, Choi Y M, Liu P, Zhou W P, Adzic R R. J Am Chem Soc, 2009, 131: 17298

[12] Ghosh T, Vukmirovic M B, DiSalvo F J, Adzic R R. J Am Chem Soc, 2010, 132: 906

[13] Fu Q Li W X, Yao Y X, Liu H Y, Su H Y, Ma D, Gu X K, Chen L M, Wang Z, Zhang H, Wang B, Bao X H. Science, 2010, 328: 1141

[14] Piela P, Fields R, Zelenay P. J Electrochem Soc, 2006, 153: A1902

[15] Schneider A, Bayer M H, Wokaun A, Scherer G G. J Electrochem Soc, 2008, 155: B783

\section{Graphical Abstract}

Chin. J. Catal., 2013, 34: 1105-1111 doi: 10.1016/S1872-2067(11)60480-4

Effect of methanol concentration on oxygen reduction reaction activity of $\mathrm{Pt} / \mathrm{C}$ catalysts

TANG Shuihua*, LIN Wenfeng, Paul A. CHRISTENSEN, Geir Martin HAARBERG

Southwest Petroleum University, China; Newcastle University, United Kingdom; Norwegian University of Science and Technology, Norway
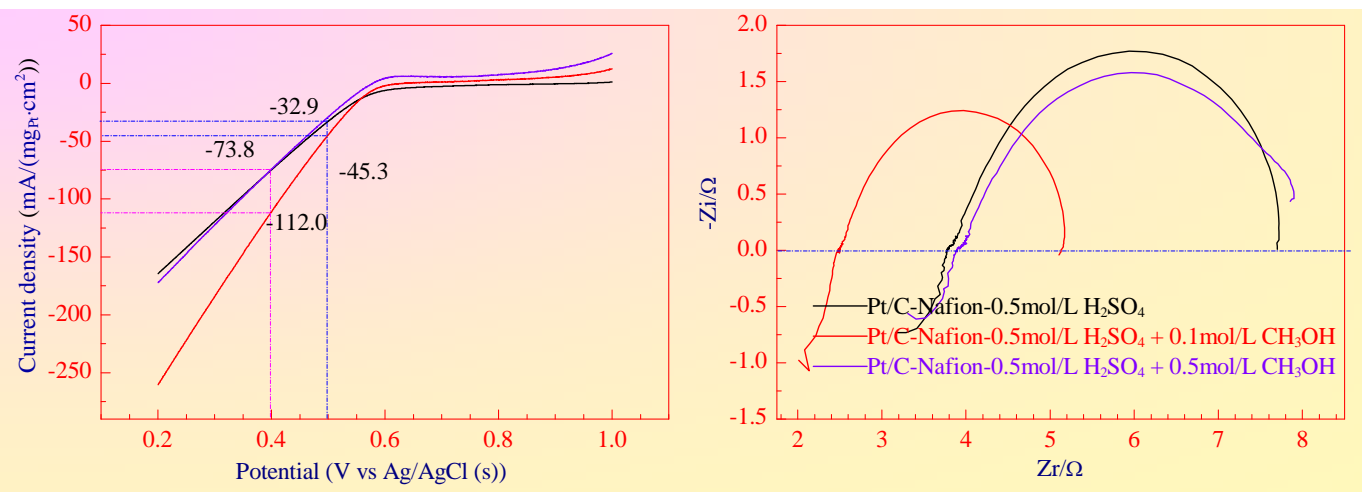

The ORR activity of $20 \mathrm{wt} \% \mathrm{Pt} / \mathrm{C}$ catalyst was enhanced notably due to a smaller resistance of Nafion membrane in the electrolyte of 0.5 $\mathrm{mol} / \mathrm{L} \mathrm{H}_{2} \mathrm{SO}_{4}$ containing $0.1 \mathrm{~mol} / \mathrm{L}$ methanol with oxygen gas feed. 
[16] Du C Y, Zhao T S, Yang W W. Electrochim Acta, 2007, 52: 5266

[17] Affoune A M, Yamada A, Umeda M. J Power Sources, 2005, 148: 9
[18] Arico A S, Antonucci V, Alderucci V, Modica E, Giordano N. J Appl Electrochem, 1993, 23: 1107

\section{甲醇浓度对Pt/C催化剂氧还原活性的影响 \\ 唐水花 ${ }^{\mathrm{a}, \mathrm{b}, \mathrm{c}, *}$, 林文锋 ${ }^{\mathrm{b}}$, Paul A. CHRISTENSEN ${ }^{\mathrm{b}}$, Geir Martin HAARBERG $^{\mathrm{c}}$ \\ a西南石油大学油气藏地质及开发工程国家重点实验室, 四川成都 610500 \\ b纽卡斯尔大学化工和先进材料学院, 纽卡斯尔 NE1 7RU, 英国 \\ ‘挪威科技大学材料科学与工程系, 特隆赫姆 7491, 挪威}

摘要: 采用半池考察了 $\mathrm{Pt} / \mathrm{C}$ 催化剂在含不同浓度甲醇的 $0.5 \mathrm{~mol} / \mathrm{L}$ 硫酸中的氧还原活性(ORR). 研究发现, 当甲醇浓度为 $0.1 \mathrm{~mol} / \mathrm{L}$ 时, Pt/C催化剂的ORR活性最高, 在催化层上热压商品Nafion NRE-212膜后也出现同样趋势. 线性扫描伏安曲线显示, 压膜前后的 $\mathrm{Pt} / \mathrm{C}$ 催化剂的ORR活性在含 $0.1 \mathrm{~mol} / \mathrm{L}$ 甲醇的 $0.5 \mathrm{~mol} / \mathrm{L}$ 硫酸中几乎没有变化. 电化学阻抗谱结果表明, 在该溶液中, Nafion膜的电 阻比在其它电解液中低, 这可能是导致Pt/C催化剂ORR活性提高的主要原因. 有必要关注Nafion膜的这一异常性质并通过特殊设 计后用于电池堆, 以提高燃料电池性能.

关键词: 铂; 炭; 甲醇渗透; 氧还原; 燃料电池

收稿日期: 2012-11-06. 接受日期: 2012-11-14. 出版日期: 2013-06-20.

*通讯联系人. 电话/传真: (028)83032879; 电子信箱: shuihuatang@swpu.edu.cn

本文的英文电子版由Elsevier出版社在ScienceDirect上出版(http://www.sciencedirect.com/science/journal/18722067). 